\title{
Intenitas Penggunaan Gawai terhadap Interaksi Sosial Mahasiswa (Studi Kasus Organisasi Primordial Ikatan Mahasiswa Tegal Wilayah Cirebon)
}

\author{
Isnin Agustin Amalia ${ }^{1}$, Alwi Zakie Yahya ${ }^{2}$ \\ ${ }^{12}$ Program Studi Bimbingan Konseling Islam, Fakultas Ushuluddin Adab dan Dakwah, \\ IAIN Syekh Nurjati Cirebon \\ Email Penulis 1: isninagustinamalia@gmail.com \\ Email Penulis 2: alwikhariri@gmail.com
}

\begin{abstract}
Abstrak
Mahasiswa IMT sangat familiar dengan gawai. Hal tersebut berdampak kepada interaksi langsung antarmahasiswa IMT yang relatif berkurang dan canggung. Tujuan penelitian ini untuk mengetahui penggunaan gawai oleh mahasiswa IMT, mengetahui interaksi sosial mahasiswa di IMT, dan mengetahui intensitas penggunaan gawai. Metodologi yang digunakan dalam penulisan ini adalah kualitatif deskriptif. Sampel responden dalam penulisan ini sebanyak 13 mahasiswa yang terdiri dari 4 orang lakilaki dan 9 orang perempuan. Hasil penelitian menunjukkan bahwa penggunaan gawai pada mahasiswa IMT sangat berpengaruh. Selain dapat memudahkan mahasiswa untuk menjalin interaksi jarak jauh, manfaat lainnya memudahkan memperoleh informasi seputar perkuliahan. Berkaitan dengan interaksi sosial, mahasiswa mengalami disfungsi sosial. Di sisi lain, intensitas penggunaan gawai terhadap interaksi sosial di IMT dalam konsteks saat berkumpul sangat mengganggu.
\end{abstract}

Kata Kunci: Penggunaan Gawai; Interaksi Sosial; Mahasiswa.

\section{PENDAHULUAN}

Perkembangan teknologi secara cepat telah membawa dunia memasuki era globalisasi yang serba maju dan modern. Pada zaman yang serba modern, manusia dituntut mengikuti perkembangan zaman yang membuat kehidupan menjadi serba praktis, efektif, dan efisien. Hal ini dikarenakan oleh kebutuhan hidup yang semakin kompleks. Oleh karena itu, diciptakanlah alat-alat yang dapat membantu kelancaran dan meringankan beban pekerjaan manusia, salah satunya adalah gawai. Isna (2013) mengatakan bahwa gawai adalah teknologi kecil yang memiliki fungsi khusus, tetapi sering diasosiasikan sebagai sebuah inovasi atau barang baru. 
Pada hakikatnya alat canggih diciptakan untuk membuat hidup manusia menjadi semakin mudah dan nyaman dalam komunikasi antar individu. Di zaman ini penggunaan gawai merupakan suatu kebutuhan yang wajib terpenuhi. Bahkan, tak sedikit mahasiswa lebih mementingkan gawai atau membeli kuota internet dibandingkan dengan membeli peralatan lain yang berhubungan dengan pendidikannya, seperti membeli buku bacaan. Padahal, kebutuhan seperti itu adalah hal yang sangat mendasar untuk mendukung perkuliahan sebagai sumber yang valid. Mahasiswa memang tak bisa lepas dari gawai. Keduanya seperti memiliki keterikatan yang sangat erat. Kebutuhan akan informasi mengakibatkan timbulnya ketergantungan terhadap gawai. Ketergantungan tersebut memang bisa dinilai positif dan negatif. Semuanya kembali lagi ke individu masingmasing.

Mahasiswa IMT sangat familiar dengan gawai. Khususnya mahasiswa yang ikut organisasi primordial. Gawai dilengkapi juga dengan berbagai fitur yang memfasilitasi para penggunanya untuk terhubung satu sama lain secara praktis. Akan tetapi, hal itu berdampak kepada berlangsungnya komunikasi secara langsung menjadi terganggu. Gawai dalam konteks ini smartphone memiliki sisi negatif baik segi berkomunikasi, kesehatan, budaya, sosial, dan sebagainya. Maka dari itu, perlu adanya batasan-batasan penggunaan gawai.

\section{METODE PENELITIAN}

Metode penelitian yang digunakan adalah kualitatif deskriptif. Menurut Burhan (2007) tujuannya untuk menggambarkan berbagai kondisi, berbagai situasi, atau berbagai fenomena realitas soasial yang ada di dalam masyarakat yang menjadi objek penulisan dan berusaha menarik realitas itu kepermukaan sebagai suatu ciri, karakter, sifat, model, tanda, atau gambaran tentang kondisi, situasi, ataupun fenomena tertentu. Populasi dalam penelitian ini adalah Ikatan Mahasiswa Tegal (IMT) Wilayah Cirebon. Sementara itu, sampel yang digunakan penulis berjumlah 13 mahasiswa dengan rincian 4 mahasiswa lakilaki dan 9 mahasiswa perempuan. Teknik pengumpulan data dalam penelitian ini, yaitu dengan menggunakan wawancara, observasi, dan studi dokumentasi. Analisis penelitian ini dilakukan dengan langkah-langkah sebagai berikut. (1) Pengumpulan informasi, melalui wawancara, dokumen maupun observasi langsung. (2) Reduksi. Langkah ini adalah untuk memilih informasi mana yang sesuai dan tidak sesuai dengan masalah penelitian. (3) Penyajian. Setelah informasi dipilih maka disajikan bisa dalam bentuk tabel ataupun uraian penjelasan. (4) Tahap terakhir adalah menarik simpulan.

\section{HASIL DAN PEMBAHASAN}

\section{A. Penggunaan Gadget Mahasiswa IMT Wilayah Cirebon}

Pada bagian ini penulis akan menguraikan beberapa pendapat mahasiswa tentang penggunaan gawai di kalangan mahasiswa IMT wilayah Cirebon. Dampak Positif Penggunaan Gadget Mahasiswa IMT. 


\section{Dampak Positif}

\section{Membantu Mahasiswa untuk Memperoleh Informasi Perkuliahan}

Interaksi merupakan suatu hubungan sosial yang menyangkut hubungan antarindividu dengan individu yang lain, antara kelompok dengan kelompok yang lain maupun antara individu dengan kelompok. Hal tersebut dapat dirasakan juga oleh Mahasiswa IMT wilayah Cirebon. Kecanggihan gawai memberikan fitur dan aplikasi yang dapat mempermudah mereka untuk memperoleh informasi perkuliahan secara cepat. Selain itu, fasilitas fitur gawai yang sering digunakan mahasiswa IMT adalah WA, Instagram, Facebook, IMO, E-book, dan Edmodo.

Seperti yang disampaikan oleh partisipan dengan inisial UF jurusan Komunikasi dan Penyiaran Islam yang di wawancarai pada Tanggal 22 Oktober 2019, mengatakan bahwa:

"Gawai itu kalo menurut saya sebagai ladang referensi ketika sedang melakukan diskusi di kelas, jika di buku tidak ada biasanya saya langsung searching untuk mencari jawaban." (1)

Begitupun yang disampaikan oleh partisipan yang bernama IF jurusan Pendidikan Agama Islam yang di wawancarai pada tanggal 22 Oktober 2019, bahwa gawai sangat membantu kita dalam mencari tugas perkuliahan.

"Kalo banyak nggak tahu tugas kuliah ya pasti searching lewat Hp, paling sering gunain itu google translite soalnya ada bahasa yang kurang dipahami kalo di perkuliahan." (2)

Tidak hanya aplikasi Chatting saja, gawai juga memberikan banyak manfaat seperti yang disampaikan oleh partisipan yang bernama MAR jurusan Pendidikan Agama Islam yang di wawancarai pada tanggal 23 Oktober yang memanfaatkan gawai untuk mempermudah mengirimkan tugas kepada Dosen dengan aplikasi Edmodo.

"Saya biasanya menggunakan Edmodo kalo kirim tugas ke Dosen atau teman, aplikasinya sangat memudahkan dan berfungsi sekali termasuk untuk saya sendiri.” (3)

\section{Membantu Mahasiswa Berinteraki dan Menjalin Hubungan dengan Keluarga, Sahabat, Teman Baik yang Berjarak Dekat Atau Jauh}

Interaksi penggunaan gadget merupakan alat komunikasi yang paling memudahkan para pengguna untuk menjalin hubungan interpersonal dengan orang tersayang. Sebagaimana yang disampaikan oleh partisipan IMA jurusan Pendidikan Bahasa Arab yang di wawancarai pada tanggal 23 Oktober 2019.

"Sebagai alat komunikasi dengan kerabat yang jauh, biar hubungan kita saling terjaga, bayangkan kalo tidak ada gadget pasti kita akan merasa kesulitan untuk mencari tahu keadaan kerabat kita. “(4) 
Tidak hanya sebatas itu saja, gawai juga memberikan kemudahan dalam melakukan berbagai transaksi atau perajalanan, seperti halnya yang disampaikan oleh partisipan UA Jurusan Tadris Bahasa Inggris pada tanggal 23 Oktober 2019.

Sangat membantu banget dong apalagi kalo lagi butuh apa tinggal pesan lewat online, kan banyak aplikasi yang sangat membantu seperti Grab atau Gojek Online." (5)

Adapun bagi partisipan MAR yang memanfaatkan gawai untuk tempat mempromosikan jasa dan produk dagangannya yang dapat memberikan peluang lebih besar.

"Saya membuka jasa pembuatan pamflet seperti pamflet ulang tahun atau pamflet acara, allhamdulillah banyak yang menghubungi baik secara online atau langsung,. Kalo online sangat memudahkan dalam melakukan promosi karena jangkauannya sangat luas ka. "(6)

Meski demikian beberapa mahasiswa juga mengungkapkan bahwa selain untuk berinteraksi dengan sesama pengguna gawai, gawai juga dapat digunakan untuk menghibur diri sendiri ketika dalam keadaan jenuh atau bosan, seperti yang disampaikan oleh partisipan UF Jurusan Komunikasi Penyiaran Islam.

"Tempat untuk hiburan kalo lagi bosan." (7)

Hal tersebut sama seperti yang disampaikan oleh partisipan yang bernama S Jurusan Perbankan syariah.

"Untuk menghibur diri mas.. ya karena dengan main game misalnya untuk menghilangkan kejenuhan."'(8)

Gawai merupakan sarana wadah ataupun memegang peranan penting untuk berinteraksi. Namun, ada beberapa mahasiswa yang lebih mengatur diri dalam menggunakan gawai untuk lebih menghargai temannya. Seperti partisipan yang bernama SL Jurusan Perbankan Syariah yang diwawancarai pada tangal 23 Oktober 2019.

"Mengabaikan Hp masing- masing saat berkumpul, kalaupun ada yang masih main hp saat akan tegur secara halus agar tidak tersinggung dan dikasih arahan kalau sedang berkumpul usahakan fokus dengan teman bukan dengan HP, silahkan HP bisa di taruh di tas dulu. " (9)

Adapun cara lain untuk menjaga hubungan pertemanan para mahasiswa lebih memilih berkomunikasi secara langsung karena akan lebih seru dan jelas jika disampaikan secara langsung.

Secara menyeluruh semua mahasiswa IMT Wilayah Cirebon yang di wawancarai mengatakan bahwa dampak negatif dari penggunaan gawai sebagai berikut. Pertama, membuat para mahasiswa mengalami disfungsi sosial. Kedua, berkurangnya waktu interaksi secara langsung. Ketiga, berkurangnya kepekaan di lingkungan sekitar karena terlalu fokus dengan HP. 


\section{Dampak Negatif}

\section{Mengalami Disfungsi Sosial}

Disfungsi sosial merupakan dampak yang paling dominan dimiliki oleh mahasiswa IMT Wilayah Cirebon karena disfungsi sosial memiliki arti bahwa kondisi seseorang yang tidak mampu melaksanakan tugas dan tanggung jawab sesuai dengan harapana orang lain. Hal ini dapat di simpulkan bahwa fungsi sosial mahasiswa IMT Wilayah Cirebon tidak berfungsi. Seperti yang dialami oleh partisipan S Jurusaan Perabnkan Syariah yang diwawancarai pada tanggal 22 Oktober 2019. Ia mengatakan bahwa separuh kehidupan ada di gawai. Apabila gawai rusak atau hilang, maka pengguna akan merasa sedih, bosan, dan gelisah.

"Sedih banget karena HP itu adalah setengah dari hidup saya dan sebagian memoriku tersimpan di dalamnya. Jika rusak atau hilang saya mencoba untuk mendapatkannya kembali. "'(10)

Begitu pun dengan partisipan NM Jurusan Perbankan Syariah, gawai merupakan kebutuhan yang penting.

"Kalo nggak ada Gadget ya pasti sedih yaa, terus juga sulit untuk mencari informasi karena zaman sekarang serba menggunakan Gadget dan pastinya akan terasaa diasingkan jika sedang kumpul bersama teman tidak mempunyai gadget." (11)

Berbeda dengan partisipan MH Jurusan Bimbingan Konseling Islam yang menganggap bahwa gawai bukan segalanya, ia merasa bahwa lebih menyenangkan jika berkomunikasi secara lagsung dan merasa santai saja jika tidak mempunyai gawai.

“Jika HP rusak, maka hadapi dengan tengan, dan biasa biasa saja.” (12)

\section{Kurang Peka Terhadap Lingkungan Sekitar}

Hal seperti tersebut banyak terjadi. Pengalaman ini hampir dialami oleh partisipan, seperti SL Jurusan Perbankan Syariah.

"Itu terjadi saat saya sedang jalan bersama dengan keluarga dipusat perbelanjaan, ibu dan kaka lagi belanja, ponakan saya lagi main tanpa disadari lepas dia dan hampir naik eskalataor sendirian dan semua orang disitupun teriak tapi saya masih nggak paham sikon, ada apa begitu kan, tpi untungnya langsung diambil oleh kakak saya." (13)

Begitu juga dengan partisipan IMA Jurusan Tadri Bahasa Arab, dia lebih fokus terhadap gawai sehingga tidak fokus dengan lingkungan sekitar termasuk tidak melihat jalan yang akan dilewati.

"Saya kan kalo jalan sukanya main HP, suka Chattingan ketika jalan, jadi kadang suka nggak liat disekitar kita ada apa ajah, waktu itu pernah sampe mau nabrak orang tapi untungnya nggak jadi." (14) 
Berbeda dengan partisipan S Jurusan Perbankan Syariah yang belum pernah mengalami hal-hal yang disebutkan partisipan sebelumnya. Walaupun fokus dengan gawai, dia masih bisa memperhatikan sekelilingnya.

"Tidak pernah sampe nggak fokus sekeliling, karena keadaan sekitar malah lebih penting, bagaimana kita mau dikenal sementara kita tidak tahu akan keadaan sekitar." (15)

Selain itu partisipan MH Jurusan Bimbingan Konseling Islam sering kali ditegur temannya karena fokus dengan Gadget apa yang temannya sampaikan tidak di dengarkan.

"Keadaan ini pernah saya rasakan ketika terdapat pesan yang sangat penting dan tidak bisa untuk dilewatkan sehingga teman teman yang berada disekiling merasa risih dan jengkel karena merasa tidak di dengarkan.”(16)

\section{Berkurangnya Waktu Interaksi Secara Langsung Berkurang}

Mahasiswa IMT Wilayah Cirebon dalam penggunaan gawai ternyata lebih lama dibandingkan dengan menghabiskan waktu bersama teman. Ketika menggunaan gawai, partisipan menghabiskan waktu paling lama selama 18 jam dalam sehari, maka ketika bersama teman- temannya hanya menghabiskan waktu kurang lebih 2-3 jam sehari. Itu pun dilakukan oleh partisian ketika berada di kampus, bertemu saat tugas kelompok. Sebagaimana yang disampaikan oleh partisipan MFR Jurusan Pendidikan Agama Islam.

"Tidur hanya 6 jam, sisanya ya buat main HP, saat dikampus juga main HP kadang ngegame, menvari berita yang terlewatkan di TV, kalo ketemu teman ya hanya sekedar saja, lebih lama menggunakan HP." (17)

Pengalaman yang sama juga di sampaikan oleh Sabila Yusria Amalia Jurusan Pendidikan Agama Islam.

"Pengunaan Gadget kurang lebih 10 jam, dari waktu 24 jam, 8 jam untuk tidur, 6 jam untuk kegiatan kampus termasuk bertemu dengan teman, belajar, mengaji, ngerjain tugas, sholat dan lain lain." (18).

Adapun partisipan yang lebih mementingan kesehatan dibandingkan terlalu lama menggunakan Gadget karena menurutnya kesehatan lebih penting dari apapun.

"Dalam penggunaan gawai lebih baik seperlunya saja karena jika berlama lama tidak baik untuk kesehatan yang akan berdampak parah pada realitas kehidupan." (19)

Berdasarkan paparan di atas, maka penulis akan mendeskripsikan lebih jauh bagaimana mahasiswa IMT Wilayah Cirebon dapat melakukan komunikasi secara langsung dengan temannya. Seperti apa yang disampaikan oleh beberapa partisipan yang dilakukan ketika bertemu secara langsung akan lebih asyik dalam berbincang apa 
pun pembahasannya tetap seru.

Partisipan yang beranama SYA Jurusan Pendidikan Agama Islam menyatakan "Paling enak yaa bertemu secara langsung ka, karena kita bisa melihat ekspresi, bisa tahu nada bicaranya seperti apa, karena kalo lewat HP itu semu, misal ini emot Ha ha ha padahal orangnya ga ketawa, terus kalo emot sedih padahal realitanya orangnya ketawa." (20)

Menurut partisipan NM Jurusan Perbankan Syariah, bertemu langsung merupakan cara untuk mengurangi salah paham.

"Lebih seru jika bertemu secara langsung, kalo menggunakan HP itu muncul rasa tidak puas, karena terkadang apa yang di ucapkan lewat HP tidak sesuai dengan raut wajah, kalo secara langsung kan lebih real." (21)

Sedangkan menurut partisipan yang bernama SA Jurusan Pendidikan Agama Islam mengatakan pertemuan secara langsung itu lebih seru dan terkadang suka tidak ingat waktu.

"Bertemu secara langsung itu seru bisa melihat mimik mukanya saat berinteraksi, dan lebih seru dan banyak ngobrolnya sehingga suka tidak inget dengan waktu”.

Partisipan merasa interaksi secara langsung itu lebih seru dan merasa sampai lupa waktu saat berkumpul.

\section{B. Interaksi Sosial Mahasiswa IMT Wilayah Cirebon}

Dalam kehidupan manusia baik dalam suatu masyarakat ataupun kelompok sosial pasti tidak terlepas dari interaksi sosial. Interaksi sosial merupakan kunci dari sebuah kehidupan yang sengaja dibentuk guna untuk memenuhi kebutuhan hidup manusia itu sendiri. Adapun syarat terjadinya interaksi sosial, yakni adanya kontak sosial dan juga komunikasi antar individu, baik secara langsung maupun secara tidak langsung.

Berlangsungnya suatu proses interaksi didasarkan berbagai faktor, antara lain imitasi, sugesti, identifikasi dan simpati. Faktor-faktor tersebut dapat kita lihat dalam interaksi yang terjadi dalam IMT wilayah Cirebon. Interaksi sosial memiliki beberapa bentuk, yakni berupa kerja sama, persaingan atau bahkan berupa pertentangan atau pertikaian. Gillin dan Gillin (dalam Soekanto, 1982) mengidentifikasikan interaksi sosial itu dalam dua bentuk, yakni proses yang asosiatif dan disosiatif. Bentuk interaksi sosial asosiatif ini terdiri dari kerja sama, akomodasi, dan juga asimilasi atau menuju kearah positif. Bentuk interaksi sosial disosiatif terdiri dari persaingan kontravensi dan juga pertikaian. Kedua bentuk tersebut mewarnai interaksi sosial dalam kehidupan manusia. Setiap dalam interaksi sosial pasti terdapat kedua bentuk tersebut karena dalam masyarakat ataupun kelompok itu terdiri dari individu-individu yang memiliki kepribadian dan watak yang berbeda-beda. 
Bentuk interaksi sosial assosiatif dapat dilihat dalam hal kerja sama antaranggota IMT dan juga akomodasi. Kerja sama itu tampak pada saat mereka menjalankan program- program kerja yang telah mereka rancang. Kerja sama yang terjalin antara anggota IMT juga dapat dilihat saat kinerja kepanitiaan. Kepanitiaan ini dibentuk ketika akan melakukan suatu kegiatan. Biasanya kepanitiaan ini diambil di luar pengurus IMT. Dalam panitia itu mereka sebaik mungkin bekerjasama demi suksesnya suatu kegiatan. IMT merupakan duta kebudayaan Tegal sehingga mereka memiliki tanggung jawab melestarikan dan mengenalkan budaya Tegal kepada khalayak luas. Di sini mereka pun bekerja sama mempertahankan kelestarian kebudayaan serta mengenalkan atau mensosialisasikan kebudayaan Tegal dengan berbagai cara, salah satunya adalah mengikuti festivalfestival kesenian dan kebudayaan.

Kerjasama ini bisa terjalin karena diantara anggota IMT telah memiliki ikatan emosional karena intensitas pertemuan dan juga karena mereka memiliki perasaan senasib. Rasa senasib jauh dari orang tua dan saudara serta senasib dalam hal samasama sedang menuntut ilmu di Cirebon. Bentuk interaksi sosial asosiatif juga tampak dalam bentuk akomodasi. Akomodasi merupakan sebuah bentuk usaha untuk mengurangi pertentangan antara orang perorangan atau antarkelompokkelompok di dalam masyarakat akibat perbedaan paham atau pandangan. Akomodasi ini dapat terlihat ketika terjadi konflik antaranggota IMT maupun pengurusnya, maka akan diadakan akomodasi guna meredakan konflik.

Bentuk interaksi sosial yang juga terdapat dalam IMT adalah bentuk interaksi sosial disosiatif. Hal ini tampak dalam unsur persaingan dan juga konflik antar anggota. Ada beberapa bidang yang bisa menjadi tempat sebuah persaingan, yakni bidang ekonomi, kebudayaan, kedudukan, dan juga kesukuan. Menurut (Santosa, 2004) setiap individiu atau kelompok pasti memiliki perbedaan baik berupa bentuk fisik, kebudayaan, pola pikir dan sebagainya. Perbedaan-perbedaan tersebut yang sering memicu terjadinya sebuah pertentangan atau konflik antar individu ataupun kelompok.

Konflik yang dialami dalam IMT sendiri ini biasanya tidak bertahan lama. Hal ini dikarenakan ikatan emosional yang dimiliki oleh semua anggota IMT. Mereka telah menanamkan dalam diri mereka masing-masing bahwa anggota IMT adalah keluarga yang dimiliki selama berada di Cirebon ini. Penyelesaian konflik yang sering dilakukan adalah musyawarah bersama. Apabila konflik yang terjadi telah memperburuk keadaan dan hubungan antaranggota, maka penyelesaian yang ditempuh adalah melibatkan para senior atau sesepuh dari IMT guna mendamaikan individu yang berkonflik. 


\section{Intensitas Penggunaan Gawai Terhadap Interaksi Sosial Mahasiswa IMT Wilayah Cirebon}

Berdasarkan hasil wawancara di dapatkan informasi dengan 13 responden ini bahwa penggunaan gawai pada zaman sekarang merupakan suatu kebutuhan seperti mempercepat sampainya informasi seputar perkuliahan, mempermudah berinteraksi, dan lain sebagainya. Dalam sehari mahasiswa IMT menggunakan gawai itu kurang lebih 10 sampai 18 jam. Adanya gawai ini bisa menjadi media untuk memperlancar proses berinteraksi mahasiswa IMT. Namun, dalam konteks saat berkumpul atau kumpulan. Penggunaan gawaiini dirasa agak mengganggu dan menghambat proses berinteraksi.

Pada akhirnya, penggunaan gadget sekarang bukan hanya sebagai gaya hidup semata, melainkan juga mendorong terbentuknya interaksi sosial yang sama sekali berbeda dengan interaksi tatap muka karena interaksi dapat dilakukan dari jarak jauh. Diketahui juga bahwa mahasiswa IMT wilayah Cirebon mempunyai rasa ketertarikan/ intensitas berinteraksi sosial yang cukup tinggi. Bentuk interaksi sosial yang juga terdapat dalam IMT adalah bentuk interaksi sosial disosiatif. Interaksi asosiatif seperti saling menginformasikan dengan lebih jelas tentang pembahasan program kepengurusan kami. Sementara itu, interaksi disosiatif yang terjadi di IMT Wilayah Cirebon adalah adanya persaingan dan konflik antar anggota.

\section{SIMPULAN}

Berdasarkan pemaparan di atas dapat disimpulkan bahwa penggunaan gawai pada mahasiswa sangat berpengaruh karena memudahkan mahasiswa menjalin interaksi dengan orang yang jauh dan memudahkan mahasiswa memperoleh informasi seputar perkuliahan secara cepat. Di sisi lain, mahasiswa pun mengalami disfungsi sosial. Interaksi sosial yang terjalin sejak berdirinya IMT Wilayah Cirebon hingga saat ini telah memberikan warna dalam perjalanan IMT. Dari interaksi sosial yang terjalin terciptanya kerja sama, persaingan bahkan konflik antara anggota dan pengurus. Intensitas penggunaan gawai terhadap interaksi sosial di IMT dalam konteks ketika berkumpul sangat mengganggu.

\section{DAFTAR PUSTAKA}

Agusli, R. (2008). Panduan Koneksi Internet 3G \& HSDPA di Handphone \& Komputer. Jakarta: Mediakita.

Burhan, B. (2007). Penelitian Kualitatif Komunikasi, Ekonomi, Kebijakan Publik, dan Ilmu Sosial lainnya. Jakarta: Kencana

Soekanto, S. (2013). Sosiologi Suatu Pengantar. Jakarta: Raja Grafindo Persada. 
196 | Amalia \& Yahya - Intensitas Penggunaan Gadget ...

Darmawan, D. (2012). Pendidikan Teknologi Informasi Dan Komunikasi.; Bandung; Remaja Rosdakarya.

Gunawan I. (2015). Metode Penelitian Kualitatif Teori dan Praktik. Jakarta: Bumi Aksara.

Partanto, dkk. (n.d.). Kamus Ilmiah Populer. Surabaya: Penerbit Arloka.

Rayan A. B. (2004). Rahasia Dibalik Handphone. Jakarta: Darul Falah.

Walgito, B. (2003). Psikologi Sosial. Yogyakarta: Andi. 